Columbia Law School

Scholarship Archive

1987

\title{
Quantity and Price Adjustment in Long-Term Contracts: A Case Study of Petroleum Coke
}

Victor P. Goldberg

Columbia Law School, vpg@law.columbia.edu

John R. Erickson

Follow this and additional works at: https://scholarship.law.columbia.edu/faculty_scholarship

Part of the Contracts Commons, and the Law and Economics Commons

\section{Recommended Citation}

Victor P. Goldberg \& John R. Erickson, Quantity and Price Adjustment in Long-Term Contracts: A Case Study of Petroleum Coke, 30 J. L. \& Econ. 369 (1987).

Available at: https://scholarship.law.columbia.edu/faculty_scholarship/2245

This Article is brought to you for free and open access by the Faculty Publications at Scholarship Archive. It has been accepted for inclusion in Faculty Scholarship by an authorized administrator of Scholarship Archive. For more information, please contact scholarshiparchive@law.columbia.edu, rwitt@law.columbia.edu. 


\section{QUANTITY AND PRICE ADJUSTMENT IN LONG-TERM CONTRACTS: A CASE STUDY OF PETROLEUM COKE*}

VICTOR P. GOLDBERG

Northwestern University and

\author{
and
}

\author{
JOHN R. ERICKSON \\ California State University, Fullerton
}

\section{INTRODUCTION}

$\mathbf{M}$

UCH economic activity takes place within a framework of complex, long-term contracts. While economists have shown increased interest in these contracts, surprisingly little is known about them, or, indeed, about how to analyze the contracting activity of private economic actors. A case study of the actual contracts used in one industry could provide sorely needed data about the way in which reasonably clever businessmen and lawyers cope with problems scholars might consider intractable. In this article, we provide such an analysis of contracts concerning a particular product-petroleum coke. We focus on the problems of quantity and price adjustment. We do not deal, except in passing, with the question of why the parties chose long-term contracts rather than short-term agreements or vertical integration by contract rather than by ownership.

In 1964, the Federal Trade Commission (FTC) launched an investigation into the possible anticompetitive effect of the long-term contracts under which eight oil refineries sold petroleum coke to the Great Lakes Carbon Corporation (GLC). The investigation culminated in a 1973 decision that these contracts violated the antitrust statutes. ${ }^{1}$ The contracts

\footnotetext{
* Part of Goldberg's research was funded by a grant from Northwestern University School of Law. Part of Erickson's research was funded by a grant from the Great Lakes Carbon Company. The paper benefited from comments at seminars at UCLA (Economics), Toronto (Law), Stanford (Law), Virginia (Law), and Northwestern (Law).

${ }^{1}$ In the Matter of Great Lakes Carbon Corporation, et al., 82 F.T.C. 1529 (1973). The record of this case and the FTC's file serve as our primary source of information. The commission's internal classification of the case is $\mathbf{8 8 0 5}$, and this number is used in referencing the location of documents. Complainants' exhibits are designated by $\mathrm{CX}$. Exhibits by the defendants are designated by GLCX (Great Lakes Carbon), TX (Texaco), and MOX (Mobil). Proposed Findings of Fact and Conclusions of Law are found at 8805-1-3-2; these are [Journal of Law \& Economics, vol. XXX (October 1987)]

(C) 1987 by The University of Chicago. All rights reserved. 0022-2186/87/3002-0005\$01.50
} 
collected by the commission in its investigation are our primary source of data. The Great Lakes Carbon record and the FTC's nonpublic files included about ninety contracts, which account for about 80 percent of all the domestic petroleum coke contracts written between 1946 and $1973 .{ }^{2}$ In addition, the FTC's Compliance Files provided us with a number of post-1973 contracts, while industry sources supplied us with a few more.

Long-term contracts enable economic actors to coordinate behavior, while stopping short of full, formal vertical integration. These contracts reflect the problems posed by the human characteristics of the transactors (their limited ability to process information, their propensity for strategic or opportunistic behavior); by the physical characteristics of the subject matter of the transaction (that is, problems with defining and monitoring quality, the production technology, the ease of access to alternative buyers or sellers, the relation-specific nature of the physical plant, and so forth), and by the reliability of external enforcement (legal enforcement or good will). These contracts embody the particular solutions developed by the contracting parties. Our working assumption here is that the solutions are correct-that is, that the contracts are "efficient" adaptations. ${ }^{3}$ On the basis of this assumption, we can then work backward and ask why particular contract terms (or patterns of terms) might be efficient. ${ }^{4}$

Two caveats are in order. First, a written contract is at best an imperfect representation of the underlying economic relation. A written document is typically an incomplete specification of the terms and conditions. Moreover, even the terms and conditions explicitly included in the contract can be changed or suspended; indeed, adjustments to changed con-

denoted by the party's abbreviation followed by an $\mathrm{F}$ (for example, Complaint Counsel's Findings are CF). Documents introduced as evidence are designated by their FTC file number. Files were usually not paginated.

${ }^{2}$ The contracts were written by thirty different sellers of petroleum coke at forty-four different refineries. (In 1970, there were thirty-five refiners operating fifty-three cokeproducing refineries.) The nature of the contracts varies considerably. Some are formal documents over twenty pages long, while others are two-paragraph letters saying that the parties renew their previous agreement with no changes. In a number of contracts, some confidential information (often concerning price) was deleted by the FTC.

${ }^{3}$ We have in mind a very narrow meaning of efficiency. The adaptations are efficient for the parties, not necessarily for any larger group (such as society as a whole).

4 The theoretical framework for analyzing complex institutional arrangements in general, and long-term contracts in particular, has been developing over the last decade or so. See Victor P. Goldberg, Relational Exchange: Economics and Complex Contracts, 23 Am. Behavioral Scientist 337 (1980); Benjamin Klein, Robert G. Crawford, \& Armen A. Alchian, Vertical Integration, Appropriable Rents, and the Competitive Contracting Process, $21 \mathrm{~J}$. Law \& Econ. 297 (1978); Oliver E. Williamson, The Economic Institutions of Capitalism: Firms, Markets, Relational Contracting, 1985; and The Economic Nature of the Firm: A Reader (Louis Putterman ed.), 1986. 
ditions are frequently made without consulting the written contracts. ${ }^{5}$ The documents will reflect the concerns of the parties as filtered through their lawyers and conditioned by their expectations regarding the reasonableness of the opposite party in adjusting to unspecified contingencies. Second, our working assumption is only a research strategy, not an article of faith. People do stupid things, and, in some instances, the best explanation of why a particular term was adopted is that the parties made a mistake. There are two countervailing forces influencing the likelihood that petroleum coke contracts would embody mistakes. On the one hand, considerable time and effort went into designing the contracts; contract terms were not simply lifted off the shelf. On the other hand, the long terms and the infrequent participation in the market by most of the buyers and sellers ${ }^{6}$ meant that contract terms were not necessarily "equilibrium" terms - that is, the results of market forces rewarding winners and penalizing losers. The contract terms meet only the weak test of birth, not the stronger test of survival.

We have chosen not to rely on three common explanations: $(a)$ the contract terms are imposed by the big and powerful on the small and weak; $(b)$ the terms facilitate anticompetitive behavior; ${ }^{7}$ and $(c)$ the contracts reflect the risk preferences of the parties. We are not asserting that any of these propositions is false; we are simply trying to see how far we can go in explaining contract structure without invoking these three arguments. This research strategy was not, of course, adopted on a whim. It reflects our view that these propositions will not be of much help in explaining the structure of these, or most other, long-term economic relations. Indeed, we can go a step further and suggest that these propositions can impede (and have impeded) research on complex exchange by providing superficially appealing answers that have discouraged search along more fruitful lines.

In the next section, we provide some background on the petroleum coke industry. Section III analyzes the structure of coke contracts, emphasizing the duration, ease of termination, locus of decisions as to quantity, and the use of commission pricing. Section IV focuses on the priceadjustment mechanisms used in the coke contracts.

\footnotetext{
${ }^{5}$ See Stewart Macaulay, Non-Contractual Relations in Business: A Preliminary Study, 28 Am. Soc. Rev. 55 (1963).

${ }^{6}$ Some of the aluminum company buyers, for example, entered into a contract with only one coke supplier.

7 This was, of course, the FTC's presumption in Great Lakes. For a complete analysis of the antitrust case, it would obviously be necessary to consider whether the contracts had a possible anticompetitive purpose or effect; that is the subject of a separate paper.
} 


\section{Petroleum Coke: Its Production, Processing, and Use}

Petroleum coking is a process that takes the heavy residual oils left over from the initial distillation of crude oil and, through the application of high temperatures, produces gas oil and petroleum coke (often referred to as "green coke"). The former can be further processed into lighter distillate fuels, such as gasoline, turbine and diesel fuels, and light fuel oil. Coke accounts for less than 3 percent of the value of a barrel of oil. If not coked, the residual oil would be processed into heavy fuel oil or turned into asphalt. Thus, coking permits a low-value residual to be upgraded to more valuable light and middle distillate fuels. In 1970, fifty-three cokers were in operation in the United States. About 15 percent of the crude oil refined in the United States was coked. ${ }^{8}$

The principal constituent of green coke is carbon, which makes up from 82 percent to 92 percent of the total weight. ${ }^{9}$ It also contains volatile matter, ash, sulphur, and trace metals. The amounts of sulphur and metals in coke depend directly on the origin of the crude oil from which it comes, and the amounts present determine the use to which it is put. High-sulphur coke, which is less valuable, is used primarily for fuel in utility boilers and cement kilns.

Most low-sulphur coke-about 40 percent of all green coke-is calcined. Calcining converts the coke from a hydrocarbon to a pure carbon. This eliminates the volatile elements, increases its hardness, and makes it an excellent conductor of electricity. At the same time, calcining reduces coke's suitability for use as fuel. ${ }^{10}$ Most calcined coke is used for the production of anodes for the electrolytic cell reduction of alumina to aluminum. ${ }^{11}$ Calcining reduces the weight of coke by $15-30$ percent and raises its value substantially. In 1970, a ton of low-sulphur green coke sold for around $\$ 10$, while a ton of calcined coke sold for around $\$ 30 .{ }^{12}$ Production of one pound of aluminum requires approximately 0.5 pounds of green coke (or about 0.4 pounds of calcined coke). ${ }^{13}$ About 3 percent of the cost of aluminum can be attributed to calcined coke. ${ }^{14}$

${ }^{8}$ Victor P. Goldberg \& John R. Erickson, Long-Term Contracts for Petroleum Coke, 2-3 (Working Paper No. 206, Univ. California, Davis, Dep't Economics 1982).

982 F.T.C. $1529,1532$.

1082 F.T.C. $1529,1542-43$.

11 In the 1970s about $75-80$ percent of the calcined coke produced in the United States was used for aluminum anodes, about half being sold to foreign users.

$12 \mathrm{CF}$, at 34 .

13 8805-4-99-3.

14 Aluminum prices in the late 1960s were about 25 cents per pound. Green coke sold for about $\$ 10$ per ton and calcined coke for about $\$ 30$. At the conversion rates noted in the text, the shares of the aluminum price attributable to green and calcined coke were 1 percent and 2.4 percent, respectively. 
TABLE 1

Calcining Plants Owned by Great Lakes Carbon, 1964

\begin{tabular}{lc}
\hline \hline Location & Capacity (tons/month) \\
\hline Port Arthur, Texas: & 3,000 \\
Started calcining operations 1935 & 9,000 \\
Added second calciner 1938 & 18,000 \\
Added third calciner 1952 & 30,000 \\
Total & \\
Calumet plant, Chicago, Illinois: & 18,000 \\
Started calcining operations 1942 & 10,000 \\
Added second and third units 1948 & $\mathbf{8 , 0 0 0}$ \\
Added fourth unit 1959 & 36,000 \\
Total & \\
Wilmington plant, Wilmington, California: & 12,000 \\
Started calcining operations 1940 & 18,000 \\
Added second unit 1952 & 30,000 \\
Total & 15,000 \\
Enid plant, Enid, Oklahoma: started November 1964 & \\
Casper plant, Casper, Wyoming & 2,500 \\
Started processing 1956 & 2,500 \\
Added second unit 1964 & \\
Total & 5,000 \\
Lockport, Lockport, Illinois: started 1937; abandoned 1958 & 7,500 \\
\hline Soun, &
\end{tabular}

SourCE.-F.T.C. 8805-4-2-1-1.

The GLC is the largest producer of calcined coke. Great Lakes' calciners, their initial dates of operation, and their capacity as of 1964, are shown in Table $1 .{ }^{15}$ Twelve other firms operate twenty-one additional calciners, with a total capacity about twice that of Great Lakes.

Great Lakes served as a middleman, selling both green and calcined coke to end users. Other calcining firms also served as middlemen. In 1959, Kaiser Aluminum and Chemical Company became the first end user to build a calciner. In subsequent years, Kaiser added five additional calciners, and three other aluminum companies also built calciners. Although the major part of their calciner output was for their own anode production, the aluminum companies did sell some calcined coke to other

15 According to industry sources, since 1964 capacity at the Port Arthur and Wilmington plants has roughly doubled, and at the Enid plant it has tripled. At the Chicago plant, it has been halved. 
final users. While there has been a substantial amount of backward integration into calcining by aluminum companies, there has been very little forward integration by refiners. Continental Oil installed a calciner in 1956 , but, by 1970 , only four of the thirty-five coking refiners had installed calciners. ${ }^{16}$

Because coke is a low-value, bulky product, transportation costs play a significant role in the economics of coking. Unless a coker has access to ocean ports, or to a calciner within a radius of fifty miles, shipping by rail is the cheapest alternative. As an indication of the magnitude of these costs, we regressed 1968 rail freight rates against distance: ${ }^{17}$

$$
F=5.41+0.0038 D, \quad R^{2}=.77, N=.85,
$$

where $F$ is freight rate per ton, and $D$ is distance in miles. That is, shipping costs independent of distance were about $\$ 5$ per ton, and shipping coke 1,000 miles costs about $\$ 4$ more. At the time, high-quality coke sold for about $\$ 10$ per ton freight on board (f.o.b.), while low-quality coke sold for about half that. Because calcined coke had a considerably higher value per pound, producers had an incentive to locate calciners near the source of supply and to transport calcined coke to the location of the end user. If a coker was located near a calciner, trucking was a reasonably inexpensive method of transport. In eleven instances, cokers and calciners were physically adjacent, so that no transportation (other than to or from the inventory pile) was necessary. Proximate location drastically reduced transportation costs, but other costs were likely to be higher. For example, it might require sacrificing economies of scale in the coking or calcining process. In addition, it could increase the contracting parties' vulnerability to opportunistic behavior by their counterparts.

The bulkiness of coke makes it expensive to store. Coke is also a fire hazard and a source of pollution unless it is put in covered storage. ${ }^{18}$ The costs of storing coke include both the direct costs of preparing land and of providing railroad spurs, water sprays, bulldozers, and loading equipment and the opportunity cost of the land employed for storage. It also must include the possible costs arising from an accumulation of inventory, an accumulation that may cause a disruption in the refinery's operations. ${ }^{19}$ Some of these costs arise regardless of whether the coke is stored at the

\footnotetext{
${ }^{16}$ More recently Arco and Gulf have built large calciners.

17 The data are from $8805-4-2-2$, pp. 276-78. The $t$-statistic is in parentheses.

18 MOF, at 31-32.

19 The production of coke has a "vast potential to disrupt the entire operation of the refinery due to its rapid accumulation" (MOF at p. 22).
} 
refinery or elsewhere. But others, notably the opportunity cost of land, depend crucially on where the coke is stored. Economizing on inventory costs requires rapid processing to keep the total inventory low and rapid removal of inventory to lower-value storage areas. As we shall see in the next section, the latter is of particular importance in explaining the variation in the structure of coke contracts.

\section{Structure of the Contracts}

The parties to a long-term contract have a mutual interest in designing a contract that maximizes its value to both parties. They also, however, have a selfish interest in achieving a large individual share, even if doing so results in a reduced overall value. If the parties could costlessly constrain their noncooperative, opportunistic behavior, contracting would not be very difficult-or interesting. Much of the structure of contracts reflects the attempts of parties to constrain their noncooperative behavior in order to increase the total pie. In our discussion, we will emphasize the pie-increasing motives; but it should be understood that the opportunism problem is omnipresent.

In the long run, the parties involved want to assure the continuation of their relation while still maintaining enough flexibility to adapt the relation to changed circumstances. The more vulnerable a party is to termination, ceteris paribus, the greater the protection it would want. Thus, a coker with ample storage space and easy access to the sea would have little reason to rely on a particular customer, and it would not insist on a very long contract term with large penalties for early termination. On the other hand, a calciner built adjacent to a coker and with poor access to alternative coke suppliers would opt for greater protection.

The parties also face a short-run coordination problem. The coker's costs depend on the rate at which coke is removed from the refinery. If coke is removed too slowly, the coker is faced with a number of costly options. It could accelerate the search for new customers, reduce the selling price, add to inventory if storage space is available, reduce the production rate, or, in the limit, shut down its coking operation. The opportunity cost of refinery products not produced is a significant element of the cost of untimely removal. Because oil companies can substitute output from noncoking operations, the cost is related to the difference between the net returns from coking and the refiner's next best alternative. The buyer also faces costs if the rate of delivery deviates from the optimal rate. If too much coke arrives, the firm would have to store it or otherwise dispose of it. If too little, then the calciner must draw down inventory, acquire coke from an alternative supplier, produce at an inefficiently low rate, or, in the limit, shut down. 
An integrated firm would face the same problem of balancing these various costs. The problems are compounded, however, when the decisions are to be made by independent firms. To facilitate coordinated, adaptive, sequential decision-making the parties could establish channels for conveying exchange-related information or set up procedures to deal with disputes, for example, arbitration. They could also build into the contract incentives for controlling the costs arising from miscoordination. Our primary focus will be on the locus of responsibility and on the incentive structures. In the remainder of this section we will focus on the means by which the contracts dealt with the long- and short-run coordination problems.

To facilitate exposition, we have divided the contracts into four groups: (1) sales of coke to Great Lakes Carbon for calcining (this covers most of the GLC contracts in the sample), (2) sales to aluminum companies, (3) commission contracts, and (4) the remainder. In an earlier draft, we included a large number of specific contract terms in the text. Most readers found that this impeded the flow of the argument. We, have, therefore, decided to omit the specific contract language and instead to paraphrase. For readers interested in the precise language, the contract terms are available separately as an Appendix. ${ }^{20}$

Great Lakes' Calcining Contracts. - A number of features common to most of the GLC contracts influenced their basic structure. The coker's capacity was usually considerably less than GLC's calciner capacity; for example, in 1963 GLC's Port Arthur calciner purchased at least 15,000 tons of coke from eight refiners and its Calumet calciner purchased a similar amount from six. ${ }^{21}$ Moreover, GLC maintained more than 250 acres for coke storage at ten different locations. The storage capacity was about 3 million tons; in 1963 and 1964, its average inventory was about 2 million tons, which was equal to about one year's purchases. ${ }^{22}$ Consequently, GLC was not particularly vulnerable to variations in the flow of coke from any single source. Sellers, on the other hand, generally had little storage capacity. If inventory was allowed to accumulate on the premises, the coker would have to shut down the coking operations. The cokers could have bought additional land-at a price-for storing coke inventory at the refinery and could have controlled-also at a price-the nuisance damages arising from storing coke at the refinery. We infer that

${ }^{20}$ Citations to this will be of the form: "Appendix, Term __." A copy of the Appendix is on file at the editorial offices of the journal.

21 8805-4-2-1-1.

22. 8805-4-2-1-1-. GLC's inventory was unusually high in those years. 
the price for doing so was too high; on net, it was more profitable for most of these refiners to have the inventory moved away from the refinery. ${ }^{23}$

Almost all the GLC contracts were full output/immediate removal contracts with GLC bearing all the risks of changes in the rate of coke output. The coker was obligated to sell only if it produced. ${ }^{24}$ The decision to produce was entirely in the hands of the coker. The coker could terminate without legal obligation if it ceased production of coke at the refinery. Termination for the purpose of selling to another buyer would, however, constitute a breach of contract. The contract was asymmetrical in that GLC did not have the option of ceasing performance without being liable for damages. Indeed, GLC typically agreed to provide immediate removal of the coke, so that a failure to remove coke rapidly enough would constitute a breach of its obligations. ${ }^{25}$ GLC's nonperformance would be excused legally only for specified conditions having to do with changes in the coke's quality or for circumstances beyond the parties' control. ${ }^{26}$

The GLC contracts were generally of long duration, especially when a new coker was involved. Nine of the ten contracts written between 1946 and 1961 involving new cokers were for a period of at least ten years. ${ }^{27}$ Contract length is, to be sure, a slippery concept. A contract might permit termination without penalty at a certain date prior to the stated termination date. For example, GLC's twenty-year agreement with American Oil gave each party the privilege of terminating with six months' notice at the end of the tenth and fifteenth years. ${ }^{28}$ The stated twenty-year term does, nonetheless, convey some information. There would be a greater presumption of renewal at the tenth anniversary than for a straight ten-year agreement; a party terminating at the reopening date would have to meet a

${ }^{23}$ Conceivably, the refiner could have shipped the coke itself, rather than relying on GLC. It could have maintained the distant stockpiles or shipped the coke to stockpiles owned by others (including GLC). Thus, GLC's 1974 contract with Mobil's Beaumont, Texas refinery gave Mobil, in the event the contract were terminated, the right to store up to 400,000 tons of coke at GLC's Port Arthur facility; the agreement was for one year, with the option on a second year as well; prices for handling Mobil's inventory were specified in the contract. This was the only instance of such a term in the contracts. It seems quite certain that forward integration into inventory removal and storage by refiners was more costly than backward integration into removal and storage by calciners.

24 Appendix, Term 1.

25 Appendix, Term 2.

${ }^{26}$ Suspension or termination of the contract for failure to meet quality standards is discussed in Goldberg \& Erickson, supra note 8, at 30-39. For a typical "force majeure" clause, see Appendix, Term 3.

27 The one exception was a five-year contract with Skelly Oil in 1958 (8805-4-2-1-1, p. 30). Skelly had considerable space available for inventory storage.

28 Appendix, Term 4. 
higher standard of reasonableness to maintain its reputation with the trade. $^{29}$

The primary determinant of contract length was the coker's need to protect its reliance interest. The small number of feasible alternative outlets for the coker meant that the value of the coker's investment would fall substantially if the relation were terminated. GLC's ample storage capacity and its multiple sources made it relatively less vulnerable. ${ }^{30}$

The Aluminum Contracts. - Ten contracts between coking refiners and aluminum producers were included in the record. Some significant features of these agreements are summarized in Table 2. Only the LaGloriaAlcoa contracts did not involve construction of either a new coker or a calciner. These agreements, not surprisingly, were for a much shorter period than the others. At three locations, the contracting parties were engaged in the simultaneous construction of an adjacent new coker and calciner.

The aluminum contracts differed considerably from the GLC agreements. Whereas, in the Great Lakes Carbon contracts, the refiner was responsible for determining whether, and how much, coke should be produced, in the aluminum contracts, the decision was in the hands of the buyer. All the contracts specified a minimum level of output. In no case did the buyer agree to take all the coker's output, even though in all but three instances the contract quantity was close to the coker's capacity. Moreover, in nine of the agreements, the coking refiner could not refuse to produce coke without being liable for damages. ${ }^{31}$

Six of the contracts allowed the buyer to reduce its purchases below the contract quantity under certain conditions. However, to provide some protection for the coker, the contracts included nonlinear pricing rules to discourage such reductions. The form these pricing rules took differed considerably. The differences are of less importance than the fact that

29 A variant was a contract for three successive three-year terms. The contract stated that the parties could not terminate solely because the price was unsatisfactory without first engaging in good faith negotiation on the price (Appendix, Term 7).

${ }^{30}$ Two of GLC's calciners were built in close proximity to a single coker that supplied all its needs. The small calciner $(50,000$ tons per year) at Casper, Wyoming, had facilities to store one year's coke. The Wilmington, California, calciner was built near Mobil's large Torrance coker (coke output of about 500,000 tons per year). The calciner had storage capacity of about eight months (8805-4-2-1-1). Moreover, Mobile had additional storage capacity for coke in the event GLC's facilities were full (CX 5). In addition, GLC had access to the ocean and shipped most of the coke to Japan; in 1964, it sold 378,000 tons to Japan, about one-third of which was calcined (CX 1305).

31 The one exception was the Humble-Kaiser agreement (CX 68). Because Humble had already accumulated a coke stockpile of 200,000 tons that could supply Kaiser's needs for four years, the cost to Kaiser of granting Humble discretion on production of coke was obviously not great. See Appendix, Term 8. 


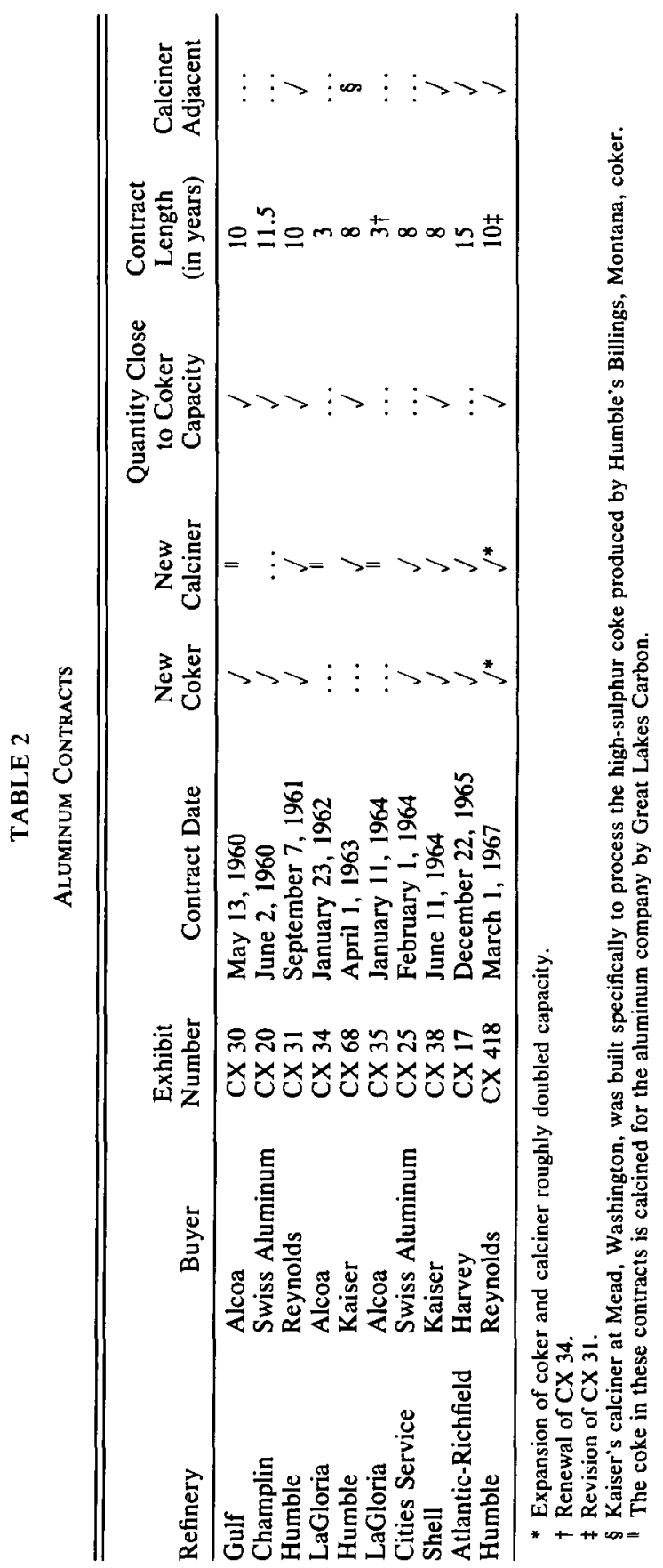


nonlinear pricing rules were common. Nonlinear pricing was only used in contracts in which the buyer had some discretion as to how much of the output it required.

Alcoa's contract involving Gulf's new coker gave Gulf the right to shut down the coker if inventory at the refinery reached 10,000 tons (twenty days' output). Alcoa would have to pay a "standby" charge during the shutdown period of $\$ 75,000$ per month. ${ }^{32}$ With the contract price at $\$ 12$ (before escalation) and the contract quantity 500 tons per day, Alcoa in effect paid for about 40 percent of the coke, whether or not it took any. Moreover, if Alcoa did not take most of the contracted amount, inventory would accumulate and the inventory constraint would quickly become binding. Alcoa could take coke at below the contract rate only if Gulf chose to produce at a reduced rate. Thus, Gulf was assured that Alcoa would have to take its interests into account when determining how much coke to take. Alcoa's contracts with LaGloria gave the coker less protection, although they still included nonlinear pricing. The price for the first 10,000 tons ( 35 percent of the contract quantity) was $\$ 14$ per ton, while the price for the remainder was only $\$ 11.25 .^{33}$

Two large cokers were constructed in conjunction with new calciners by Humble (with Reynolds) and Richfield (with Harvey). The HumbleReynolds contract was entered into in September 1961, and the coker and calciner were in operation by spring $1963 .{ }^{34}$ Reynolds agreed to take a minimum of 330,000 tons of coke per year, a quantity that it would either use itself or resell. Reynolds had the right to reduce its obligation if its estimated domestic aluminum primary ingot production were to fall below 420,000 tons per year. Since this output level would require only about 210,000 tons of petroleum coke, Reynolds in effect agreed that, in the event of a decline in demand for its aluminum, it would be fully responsible for disposing of the 120,000 tons of coke not needed for its own operations. For each ton by which Reynolds' projected aluminum production fell below 420,000 , Reynolds was relieved of taking 0.78 tons. ${ }^{35}$ Since its own coke usage would decrease by 0.5 tons, Reynolds' obligation to sell coke on the open market was reduced by 0.28 tons. Reynolds was obliged to pay 50 percent of the contract price whether or not the coke was produced. ${ }^{36}$

\footnotetext{
32 Appendix, Term 11.

${ }^{33}$ Appendix, Term 12.

${ }^{34}$ See CX 31. The contract was for ten years from the date of first delivery with two fiveyear renewal periods.

${ }^{35}$ The minimum obligation was $(330,000 / 420,000)$ times the projected aluminum output.

${ }^{36}$ Appendix, Term 13.
} 
In 1967 , the contract was revised since "Reynolds, because of the projected need for additional green . . . coke, has requested Humble to increase the quantity of green . . . coke supplied by it to Reynolds." 37 The new agreement was for 600,000 tons. The arrangement for dealing with a reduced demand for Reynold's aluminum was carried over to the new contract with only minor changes in the numbers. This contract added a new wrinkle by reducing the marginal price; the first 430,000 tons each year cost $\$ 12.50$ while the price for the remainder was $\$ 10.50$.

Since Reynolds' projected coke requirements for the early 1970 s were only about 500,000 tons per year, the contract committed Reynolds to becoming a serious marketer of calcined coke. ${ }^{38}$ Vertical integration into marketing enabled Reynolds to provide additional assurance to Humble that it stood ready to remove Humble's coke. This arrangement enabled Humble to achieve greater economies of scale than would have been possible if Reynolds were the only buyer and if it had agreed to take a smaller amount that was closer to its actual needs, or if it had agreed to a requirements contract. ${ }^{39}$

Alternatively, the parties could have set the quantity at the calciner's capacity and relied on other middlemen to remove the remaining coke. This is, in effect, what Richfield and Harvey did. Harvey agreed to construct, on land leased from Richfield and adjacent to Richfield's Watson, California, refinery, a calciner capable of handling about one-fourth the refinery's coke output. Richfield agreed to maintain a sufficient inventory of coke to assure a constant monthly flow of coke to keep Harvey's calciner operating at full capacity. ${ }^{40}$

The Richfield-Harvey contract period was fifteen years; however, under certain circumstances the contract could be terminated after only eight years (with two years' notice). The lease established a schedule of payments that was unrelated to the quantity of coke. Thus, by charging one price for the land and a second price per ton of coke, the parties established a two-part pricing system. The contract price of $\$ 3.10$ per ton was only about one-quarter the current market price of equivalent quality coke, while the rental fee was above the fair market rate.

Richfield had two other buyers of coke from the Watson refinery. Mitsui had a one-year, renewable, fixed-price contract for $50,000-70,000$ metric tons per year for sale to Japan; Mitsui had the exclusive right to

${ }^{37} \mathrm{CX} 418$. The contract was to run until the end of December 1978; it also had two fiveyear renewal periods.

${ }^{38}$ 8805-4-99-3.

39 A requirements contract would have imposed all the risks of demand fluctuations on Humble and would have drastically reduced the protection of its reliance interest.

40 Appendix, Term 14. 
sell Richfield's coke in Japan and agreed not to sell coke outside Japan without Richfield's consent. ${ }^{41}$ Wilson Carbon had an exclusive right under a six-year commission contract to sell Richfield's coke anywhere in the world other than to Harvey or in Japan. Wilson agreed to take a minimum of 200,000 short tons. ${ }^{42}$ Thus, in the three contracts combined, Richfield had firm commitments to remove about two-thirds the coker's capacity. For the remaining one-third, Wilson had the first option, but Richfield reserved the right to determine whether the additional coke should be produced. ${ }^{43}$ Mitsui and Harvey had lesser claims on coke beyond their contract maximum. Mitsui would be able to buy coke that Richfield had available at the contract price. ${ }^{44}$ Harvey's contract terms did not carry forward to any additional sales. ${ }^{45}$

Commission Pricing.-Only two GLC contracts and none of the aluminum contracts utilized commission pricing. In contrast, nearly half the contracts involving other middlemen set the contract price as a fraction of the buyer's resale price. Other things being equal, commission pricing is more attractive the less the buyer does to the coke before reselling it. That is, commission pricing is easier to arrange and police if the reseller simply takes the order and arranges to ship the coke out of stockpiles maintained by the refinery than if he stores the coke, combining it with coke from other producers, or processes the coke (for example, calcining it).

Commission pricing was the standard for low-quality (high-sulphur) coke. The price to the middleman was usually 95 percent of the price at which the coke was resold. The contracts often covered the entire coker output, but they differed from GLC's contracts by allowing for intermediate storage.$^{46}$ Cokers promised to provide in advance an approximate schedule of coke production to facilitate the buyer's planning, but they refused to be bound by that schedule. ${ }^{47}$ The contracts were for a much shorter duration than those involving calcinable coke. Contracts were typically for less than five years and termination was on relatively short notice. $^{48}$

${ }^{41} \mathrm{CX} 18$.

${ }^{42}$ CX 19; Appendix, Term 17.

43 Appendix, Term 18.

44 Appendix, Term 19.

45 Appendix, Term 20; Cities Service's coker at Lake Charles, Louisiana, also allowed for achieving scale economies in coking by having the coker contract with additional marketers. For Cities Service's method for allocating the uncommitted coke to the primary buyer, see Appendix, Term 21.

${ }^{46}$ Appendix, Term 22.

47 Appendix, Term 23.

48 Appendix, Term 24. 
Commission pricing has a number of desirable properties. It provides, as a side effect, an automatic mechanism for adjusting prices over the life of the agreement. (The advantage of price adjustment will be discussed in the following section.) It also reduces the refiner's incentive to "cheat" in the quality dimension; the parties could therefore devote fewer resources to specifying quality and monitoring performance. Indeed, most of these contracts did not specify quality. ${ }^{49}$

Contracting parties can avoid some of the ex ante costs of gathering information by using commission pricing. With a fixed-price contract, the middleman has an incentive to line up resale contracts before negotiating the initial price. The coker also has an incentive to acquire information on the resale market lest the middleman use the additional information to extract the lion's share of the rewards. Commission pricing reduces the value of special price information and, therefore, permits the parties to develop the information in a more timely, less costly manner. ${ }^{50}$

One problem with commission pricing is that it impairs the middleman's incentive to search for customers willing to pay a high price. The reseller would be indifferent between price/effort combinations that yielded the same expected profit. The refiner, however, would not be indifferent since its compensation would depend on the resale price. It would prefer the high-price/high-effort combination. To guard against the reseller's choosing the "quiet life," the commission contracts typically included a ceiling on inventory accumulation and a minimum average price. ${ }^{51}$ The minimum price was renegotiated frequently (often quarterly), and, if the parties could not agree on a minimum price, the contract would be terminable on short notice (often thirty days). However, the seller agreed not to offer to sell coke at or below the price offered by the reseller-the reseller could, in effect, match any outside offer. ${ }^{52}$

Great Lakes Carbon's two commission contracts nicely illustrate the complications that arise when the reseller does more than simply take orders for shipment from a stockpile maintained by the coker. Both in-

\footnotetext{
49 Most contracts not using commission pricing did specify quality standards. They also spelled out the procedures for measurement and dispute settlement and established rules for dealing with coke that did not meet the quality standards. See Goldberg \& Erickson, supra note 8 , at $30-38$.

s0 For similar arguments on the benefits of constraining "oversearching," see Roy W. Kenney \& Benjamin Klein, The Economics of Block Booking, 26 J. Law \& Econ. 497 (1983); Yoram Barzel, Some Fallacies in the Interpretation of Information Costs, $20 \mathrm{~J}$. Law \& Econ. 291 (1977); and Yoram Barzel, Measurement Costs and the Organization of Markets, 25 J. Law \& Econ. 27 (1982). The same basic argument is used in the following section to explain why parties might find price-adjustment mechanisms to be mutually beneficial.

${ }^{51}$ For inventory ceilings, see Terms 22 and 24; for minimum price, see Terms 25 and 26.

52 Appendix, Term 28.
} 
volved new cokers being constructed in the Los Angeles area in the late 1960s. Each coker could hold up to two months of inventory, so that timely removal, while desirable, was not as critical as it was for other cokers dealing with GLC. The coke had a low-sulphur content, but there was not sufficient calcining capacity in the Los Angeles region to process it. This coke was destined for shipment outside the region; primarily to Japan.

The term of these contracts was substantially shorter than the other contracts involving new cokers-(three and five years, respectively). This shorter term reflects the coker's lesser reliance on a single purchaser. GLC had an advantage over other middlemen when the initial contracts were signed, since it already had extensive customer contacts in Japan, as well as ample storage capacity on the West Coast. ${ }^{53}$ However, performance of the contract tended to erode its advantages vis-à-vis potential competitors. Because information developed by GLC regarding the existence of customers was revealed to the coker, GLC's market development effort was made available to potential competitors. ${ }^{54}$ Indeed, both contracts were subsequently lost to competitors.

The inventory constraint meant that coke had to be removed even if it had not yet been sold. Therefore, the price to GLC was not set as a percentage of the f.o.b. price; it was set at 90 percent of the net resale price-resale price minus the costs incurred by GLC in reselling the coke if these costs had not been reimbursed by the customer. ${ }^{55}$ This is similar to f.o.b. pricing, except that the costs of reselling are paid in what amounts to a cost-plus arrangement. ${ }^{56}$ The contracts included complex variants on the minimum average price arrangement of other commission contracts. If the costs of resale exceeded the price, the coker would refund the excess to GLC. In that event, however, the coker would have the option of suspending deliveries to GLC. ${ }^{57}$ The importance to the coker of removing inventory meant that it would be willing to accept a minimum average price of zero.

53 In 1965, GLC exported 192,000 tons of noncalcined, high-quality (low-sulphur) coke to Japan; this was about 80 percent of the coke in this category exported by American firms. It accounted for about 90 percent of the calcined coke exported to Japan. See CX 1307.

${ }^{54}$ Because the price paid by GLC depended on GLC's selling price and its selling costs, the contract required that GLC make all materials related to costs available to the coker. See Appendix, Term 30.

ss The costs included (a) all freight and other transportation charges, $(b)$ all handling and storage charges, $(c)$ the cost of any sizing of coke which in GLC's opinion increased the total market value of the coke more than the cost of processing, $(d)$ bona fide selling commissions paid to third parties, and $(e)$ taxes (CX 14).

56 Appendix, Term 31.

57 The two contracts treated this slightly differently; see Terms 32 and 33. 
The coke covered by these agreements was either shipped directly to Japan or moved to GLC's storage facilities, where it was commingled with coke from other sources for subsequent shipment to Japan. If commission rates differed, or if some of the coke in GLC's inventory were purchased at a fixed price, then GLC would have an incentive to act opportunistically in designating the source of a particular shipment. The contracts provided a mechanism for constraining such behavior. If the average net price for a calendar year exceeded the average net price of all "Western Coke" 58 sold by GLC in that year, then GLC would have to repay the excess multiplied by the number of tons delivered under the contract during the year, GLC was responsible for determining the average selling price, but the seller had the right to require an audit, the cost of the audit being borne equally by the two firms. ${ }^{59}$

Other Contracts.- - Union Oil and Collier entered into two contracts involving construction of an adjacent calciner and coker at two California locations-Oleum and Santa Maria. The agreements (CX 43, CX 66) illustrate nicely some of the points made above. The contracts were similar in a number of respects. Both were for full output of the coker and gave Union Oil the option of suspending, reducing, or discontinuing production of coke. Both were for long periods-the Oleum contract was for ten years $^{60}$ and the Santa Maria contract for twelve. However, there were significant differences, which stemmed largely from the availability of inventory storage capacity at the two sites. The Oleum site could store less than six months of coke output, while the Santa Maria site had a twoyear capacity.

At Santa Maria, the stockpile was Collier's only protection from supply disruptions. ${ }^{61}$ At Oleum, the contract included a very elaborate package that provided Collier with considerably more assurance of a continued supply. It also provided less assurance of removal than did the Santa Maria or GLC contracts. ${ }^{62}$ The contract called for a minimum quantity of 1 million tons over ten years-approximately 40 percent of the coker's capacity. In the event that Union's production at the Oleum plant was reduced or discontinued (so that the minimum would not otherwise be

58 For a precise definition, see Appendix, Term 34.

59 In both contracts, an independent third party would determine the average selling price if the parties disagreed; see Appendix, Term 30.

60 The contract was amended after two years and extended for an additional one-and-ahalf years (CX 44).

61 Appendix, Term 35.

${ }^{62}$ Collier received less assurance of a continued supply than did the aluminum companies. It also undertook a greater commitment to remove coke than did the aluminum companies. 
obtained), it agreed to make up the deficiency with coke of similar quality from other sources at the contract price.

If inventory at the Oleum coker reached 50,000 tons (three months' output), Union could either offer it for sale (giving Collier the option to take the coke at a price 10 percent below the outside offer) or require Collier to remove the coke. In the latter event, Collier would pay only 50 percent of the contract price. ${ }^{63}$ Thus, when there was external evidence of slack demand (inventory accumulation) and Union had confirmed this evidence through its inability to find buyers at prices below the contract price, Union would then share the cost of the demand reduction.

Carbon product producers were typically content to purchase their coke from middlemen. However, in some instances such producers chose to contract directly with a coker. The coker generally had more than one customer for its coke and was capable of carrying a reasonable amount of inventory; it was not purchasing removal services. As a result, the contracts typically gave very little protection to the reliance interest of either the buyer or the seller.

The carbon product contracts were either requirements contracts or for a fixed quantity. ${ }^{64}$ The seller was obligated to deliver coke only if it produced. It had the right to determine whether, or how much, to produce. ${ }^{65}$ If the seller did not produce sufficient coke, the buyer would be free to meet its needs elsewhere and would have the option of terminating the contract on short notice. ${ }^{66}$ The term of the contracts was short-from one to five years. Moreover, in some of the agreements, the buyer had the right to shop for a better price. If the seller did not elect to meet the lower price, the contract could be terminated on short notice. ${ }^{67}$

\section{Price Adjustment}

The parties did not enter into multiyear contracts in order to make bets on the future course of prices. Rather, they entered into these agreements

63 Appendix, Terms 36 and 37.

64 Air Reduction accounted for all three of the requirements contracts (CX 23, CX 39, CX 420).

65 Appendix, Term 42 and 43.

${ }^{66}$ Appendix, Term 44.

67 The three Air Reduction contracts fixed price for a period after which the buyer could search for a lower price. In the 1962 agreement, the initial price was firm for eighteen months, but this dropped to nine months in 1964 and zero months in 1967. See Appendix, Term 45. In a letter to the commission, a Union Carbide executive noted regarding one of its agreements with Cities Service: "Carbide ascertained it could procure comparable coke at a lower price. As the Carbide contract with Cities Service included a price protection clause, and Cities Service indicated it was unwilling to meet the lower offer made to Carbide, the contract was terminated according to its terms"' (8805-4-2-1-4). 
for the reasons developed in Section III. Having done so, they had to make some decisions regarding the price during the life of the agreement. ${ }^{68}$ While they could simply establish a single price or a schedule of future prices that would be in force for the entire period, they also had the option of providing some mechanism for adjusting prices in light of changed circumstances. Nearly 90 percent of the pre-1973 contracts and all of the post-1973 contracts did provide some price flexibility.

Indexing is the most obvious price-adjustment mechanism, but there are others as well. The parties could simply agree to renegotiate price either at fixed dates (for example, quarterly or annually) or at one side's request. A hybrid mechanism involving indexing and negotiation utilizes an index with a maximum-minimum limitation. If the indexed price falls outside the predetermined range, the parties can either continue at the ceiling (or floor) price or renegotiate the agreement. Another way of adjusting to changing market conditions is to allow the parties to solicit outside offers and then permit the other party to match the offer. Commission pricing, by its very nature, automatically links the contract price to external market conditions.

Indexing has the obvious advantage of being easy to implement and beyond the control (usually) of the parties involved. It also has the obvious disadvantage of not tracking changing conditions perfectly. Ceteris paribus, the lower the correlation between an index and the "correct" current price, the less attractive will indexing be. Renegotiation has the advantage of allowing the parties to use accurate, current information in revising the contract. It also, of course, suffers from the fact that reopening the contract can result in strategic behavior, especially if one of the parties is vulnerable to a threat of nonrenewal. Other things being equal, the greater this vulnerability, the less attractive would be the prospect of renegotiating.

Given that price adjustment can be difficult and costly, why bother? What are the benefits to risk-neutral firms? We will suggest three reasons for incorporating a price-adjustment mechanism into a contract; only the last two, we believe, are apposite in the case of coke contracts.

First, adjusting the price to keep it in line with current market prices gives the parties the proper short-run price signals. If the parties have much discretion regarding the short-run quantity of coke, this could be important. However, for most coke, this is not the case. Coke is a byproduct for the coking refiner; the buyer-especially Great Lakes Car-

68 This does not mean that price problems have no effect on the structure of the contracts. As we show below, the increased rate of price change post-1973 did influence contract structure. 
bon-often bought the coker's entire output. Quantity was determined by the demand for the refiner's lighter distillates, not for coke. Indexing a coke price to the market for this reason would be similar to indexing a home mortgage to the current rental rate so that homeowners could better take into account the opportunity cost of being their own tenants.

Two alternative reasons appear to be more plausible for explaining the usage of price adjustment mechanisms in petroleum coke contracts: reduction of precontract search and postagreement incentives to breach or behave opportunistically. ${ }^{69}$ In both these explanations, the success of price adjustment depends on its ability to reduce the variance of outcomes. The reduced variance is not, however, valued for itself. Rather, it enables the parties to curtail behavior that is mutually harmful, thereby increasing the value of the agreement to both parties.

A party contemplating entering into a contract has an incentive to increase its expected share of the gains from trade by expending resources to improve its information on the future course of costs and prices. The more each spends to achieve an informational advantage, the smaller the pie. Ceteris paribus, the larger the variance of the outcomes, the more resources would be devoted to this effort. The parties have an incentive to incorporate into the initial agreement a device that would discourage this wasteful searching. By reducing the value of special information, priceadjustment mechanisms can do precisely that.

If, after the firms enter into a long-term agreement, the contract price differs substantially from the market price, then the loser could be reluctant to continue the agreement. In this event, the loser could breach and suffer the legal and reputational consequences. There are, however, a number of less severe alternatives to willing compliance. A buyer could, for example, insist on strict compliance with the quality standards; he could remove coke from inventory at a slower pace than otherwise; or he could read the contract literally - "working to the rules" as often happens in labor disputes or in centrally planned economies. If the probability of such wasteful behavior increases as the divergence between contract and market price widens, rules that narrow the gap-priceadjustment rules-become increasingly attractive.

The Pre-1973 Contracts. - None of the pre-1973 contracts was indexed specifically to changes in the aggregate price level. ${ }^{70}$ Only five used a

\footnotetext{
69 This argument is developed in Victor P. Goldberg, Price Adjustment in Long-Term Contracts, 1985 Wisconsin L. Rev. 532.

${ }^{70}$ Since changes in costs or in the market price concern changes in nominal values, adjustments for them implicitly involve some adjustment to changes in the overall price level. In this sense, all of the coke contracts that provided some price flexibility contain some mechanism for adjusting, albeit imperfectly, to changes in the overall price level.
} 
TABLE 3

Maximum-Minimum Price limitations for Great Lakes Carbon Contracts, Pre-1973

\begin{tabular}{lccccc}
\hline \hline Seller & $\begin{array}{c}\text { Exhibit } \\
\text { Number }\end{array}$ & Contract Date & Base (\$) & $\begin{array}{c}\text { Maximum } \\
(\$)\end{array}$ & $\begin{array}{c}\text { Minimum } \\
(\$)\end{array}$ \\
\hline Sunray DX & CX 9 & March 1, 1957 & $\ldots$ & 15 & 8 \\
CRA & CX 408 & January 18, 1957 & $\ldots$ & 15 & 8 \\
CRA & CX 409 & March 7, 1963 & $\ldots$ & 15 & 8 \\
NCRA & CX 410 & March 19, 1957 & $\ldots$ & 10 & 4 \\
NCRA & CX 411 & January 29, 1963 & $\ldots$ & 10 & 4 \\
NCRA & CX 412 & July 22, 1963 & $\ldots$ & 10 & 4 \\
Ucan & $8805-4-2-1-6$ & March 1, 1957 & 10 & 15 & 8 \\
Derby & $\mathbf{8 8 0 5 - 4 - 9 9 - 1}$ & April 30, 1968 & 10.50 & 15 & 7 \\
La Gloria & CX 34* & January 23, 1962 & $12.00 \dagger$ & 18.50 & 7.50 \\
La Gloria & CX 35* & February 11, 1964 & $11.25 \ddagger$ & 18.50 & 7.50 \\
\hline
\end{tabular}

* La Gloria sold to Alcoa. Most of the coke was shipped directly to Great Lakes' calciner at Post Arthur for calcining on Alcoa's account.

$\dagger$ The base price of coke shipped directly to Alcoa was $\$ 14.75$.

$\ddagger$ The base price of coke shipped directly to Alcoa was $\$ 14.00$.

broad-based measure of inflation-one utilizing the Wholesale Price Index (WPI) and the other four the WPI for other than farm products and food (and three of these four adjusted prices only on an annual basis) ${ }^{71}$

Over half the pre-1973 GLC contracts utilized a price index, and all except two of these had a maximum-minimum limitation. In all but one, the index was based on the price of the crude oil supplied to the refinery, with the price being adjusted either whenever the posted crude price changed or at monthly or quarterly intervals. Four of these contracts supplemented the crude oil index with an index of wages of oil refinery workers and one also included an adjustment for the WPI nonfarm component. ${ }^{72}$ The actual maximum-minimum limitations were deleted by the FTC in most instances, ${ }^{73}$ and all that remains is shown in Table 3. This skimpy evidence suggests that the price could diverge from the base by around 20-50 percent before reaching the ceiling (or floor).

GLC renegotiated rather than indexed at only three cokers prior to 1966. However, from 1966 through 1973, only three of the fourteen contracts included a price index. Of the remainder, two contracts utilized commission pricing (which implicitly indexes to the market price), and

${ }^{71}$ 8805-3-3-2, p. 5; CX 3, CX 24, CX 25, and CX 31.

72 The three contracts that adjusted for crude oil and wages weighted the two equally (CX 1, CX 2, CX 6); the contract which indexed for crude, wages, and the WPI component weighted the three $.75, .15$, and .10 , respectively.

${ }^{73} \mathrm{CX} 1, \mathrm{CX} 2, \mathrm{CX} 4, \mathrm{CX} 6, \mathrm{CX} 8, \mathrm{CX} 10, \mathrm{CX} 12$, and CX 416. 
two were for one year or less. In the other seven contracts, price adjustment was accomplished by negotiation.

These contracts typically invoked the intentions of the parties to continue the agreement; negotiations were to be undertaken in "good faith," and in the event that negotiations failed, the current price would continue for a period of time-usually six to eighteen months-after which the agreement would terminate. ${ }^{74}$

Prices could be revised even if the contract did not explicitly provide for changes. The record contains numerous examples of price reductions to Great Lakes Carbon (and to others) during the slump in 1962-65. ${ }^{75}$ Letters from two of GLC's suppliers give an indication of the nature of the revisions:

As we explained to you this price increase to the March 19, 1957, contract level was requested and made only after the most careful consideration of all factors involved. As you know, we have now been on the reduced price basis for two years. We have been happy to work with Great Lakes throughout the years even to the extent of granting price relief when requested by your people. (CX 413)

This is to confirm our discussion of June 17 at which time we agreed to abrogate the terms of our contract covering petroleum coke produced at our El Dorado Refinery for six months starting July 1, 1965. This is a contract dated June 27, 1956 as amended January 31, 1957 and October 2, 1959. In order to give you some assistance in your marketing program, we will invoice all shipments of El Dorado coke production between July 1, 1965 and December 31, 1965 at — per ton, F.O.B. El Dorado. It is understood that this revised price will apply only to the production during the indicated six months and that the other terms and conditions of the basic contract are unchanged. In the absence of any subsequent agreements, the price will revert to the contract schedule of - per ton, effective January 1, 1966. (CX 53)

These nonmandated price reductions were undoubtedly a factor in the increased reliance on renegotiation in the 1966-73 contracts. The favorable experience with voluntary renegotiation indicated that the costs associated with opportunistic behavior when the contract price is renegotiated need not be prohibitively high. ${ }^{76}$ Moreover, the voluntary reductions reflected the failure of the price index to track market conditions accurately. That is, the expected costs of renegotiation fell at the same time that the expected benefits of indexing declined.

Most of the non-GLC middleman contracts either were commission contracts or utilized a simple price index. In only three instances did the

\footnotetext{
74 Appendix, Term 60.

${ }^{75}$ CX 50, CX 51, CX 52, CX 53, CX 409, CX 411, CX 412, CX 413, CX 1323, and MOX 41. Revisions of prices in non-GLC contracts are illustrated in GLC 7, CX 405, and CX 406.

${ }^{76}$ Contrast this to the aluminum contracts discussed below.
} 
parties explicitly state that price adjustment would be accomplished by negotiation, and one of these was not quite an arm's length agreement. ${ }^{77}$

Where aluminum companies constructed new calciners in reliance on supply by a particular coker, the contract price was typically fixed for a substantial period (see Table 4) ${ }^{78}$ The only instance in which this was not so was the first Humble-Reynolds agreement. When that was revised, however, the parties eliminated the elaborate indexing formula (which covered over two pages in the 1961 agreement) and instead fixed the price for ten years. A similar adjustment was made in the arrangement between Mobil and Union Carbide (rows 6 and 7 of Table 4). The parties abandoned monthly indexing and instead agreed on a fixed price for the duration of the contract.

The substantial length of the period over which prices remain fixed in these contracts stands in sharp contrast to what existed in other petroleum coke contracts. The fixed price agreements all date to the period in which GLC was making the transition from indexing to negotiated price adjustment and most likely are a response to the same underlying factors - namely the poor correlation between available indexes and market conditions. Why was there a more exteme response in the aluminum contracts?

The aluminum contracts generally entailed greater insulation from current market conditions. Reopening a contract would mean that the parties would haggle over how to share the pie. The more the parties are isolated from alternative trading partners, the larger the size of the pie to be shared. The larger the pie, the more resources the parties would devote to pursuing it. That is, the higher reliance interest in the aluminum contracts would result in higher renegotiation costs, making frequent renegotiation relatively less attractive.

Moreover, the "good will" sanction would be a less effective constraint on negotiations for aluminum producers than for GLC. The past track record of GLC enhanced the coker's confidence that it would negotiate price adjustment in good faith, and its continued dealings with a large number of suppliers made maintenance of this good reputation worthwhile. The aluminum companies had neither the track record nor a large incentive to maintain their reputation for fair dealing in this market. Reynolds and Harvey, for example, had no other contracts.

The Post-1973 Contracts. - The petroleum coke industry was subjected to two major shocks in 1973. On June 5, the FTC handed down its deci-

77 8805-4-99-2, 8805-3-4, and CX 41. The last contract was between a coker and a joint venture of which the coker owned 50 percent

${ }^{78}$ Appendix, Term 66. 


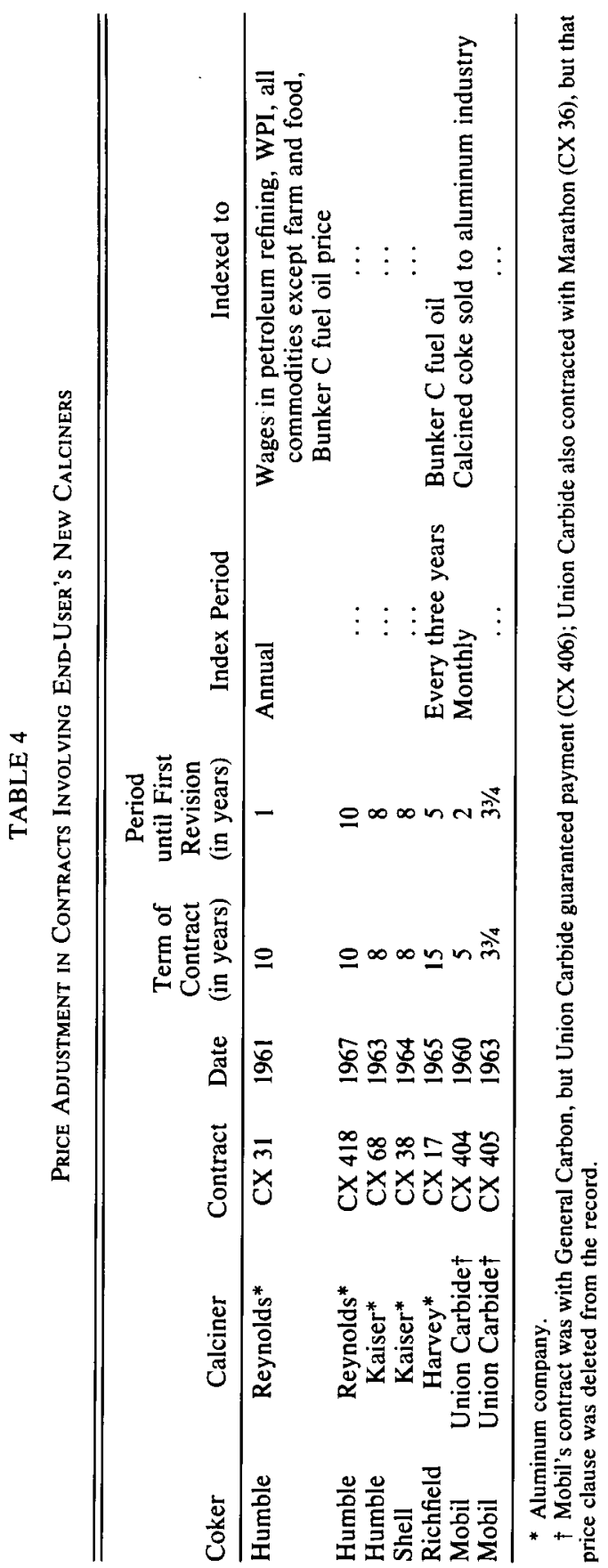


sion finding Great Lakes Carbon's long-term contracts in violation of the antitrust laws. The remedy required that GLC amend all its existing contracts so that they would extend for a period no longer than three years and all new GLC contracts be for a maximum of three years. ${ }^{79}$ The remedy also restricted the length of the contracting period for the eight oil company respondents. The restrictions on contract length did not apply to other buyers or sellers of coke. The other shock was a tremendous increase in volatility in both the crude oil and the aluminum markets. Between 1973 and 1979 , green coke prices rose from about $\$ 13$ to $\$ 60$, while calcined coke prices rose from about $\$ 30$ to $\$ 120{ }^{80}$

Our ability to trace the effect of the post-1973 changes in the structure of petroleum coke contracts is limited by the availability of data. We have twenty-nine Great Lakes contracts ${ }^{81}$ but we have had access to only a handful of contracts involving other buyers. After analyzing the GLC contracts, we will discuss briefly the changes in the contracts involving aluminum companies.

Most of the GLC contracts contained a clause that reflected the restrictions imposed by the Commission's decision. The term was three years, and the parties could not extend the term of the contract prior to six months before the date at which the contract would expire. ${ }^{82}$ The only contracts that were not for three years were a series of one-year contracts with Continental and a one-year contract with Midland in 1974 (which was succeeded by a three-year agreement). In both cases, GLC's last contract with the refinery prior to the FTC's decision was for only nine months, ${ }^{83}$ so the short term of the postdecision contracts at these refineries was not related to the changed circumstances in the petroleum coke market. It is

79 There were three exceptions: (a) if a new coker or calciner were involved, the maximum contract length was five years; (b) the limitation only applied if GLC took more than 50 percent of the coker's output (which had always been the case for its long-term contracts); (c) it could offer a longer term if it were meeting a competitive offer in good faith (so long as the offer was not from a new entrant).

${ }^{80}$ See Goldberg \& Erickson, supra note 8, at Tables 9 and 10.

81 Twelve of the contracts were from the Compliance File, 8805-3-3-2; the remainder were made available to one of the authors by Great Lakes' counsel. Some of the contracts were amended to increase prices. The commission's restrictions on renewal prevented the parties from extending the term of the agreement. If these amendments are not counted as "contracts" then the number of contracts falls to 25 .

82 Appendix, Term 67. The six-month renewal period was also mandated by the Commission: "It is further ordered, that respondent Great Lakes Carbon Corporation, its successors and assigns, shall not renew or extend any existing contract for the purchase or marketing of an amount in excess of fifty percent $(50 \%)$ of the estimated annual production of petroleum coke at any refinery more than six (6) months prior to termination of the contract being renewed or extended" (82 F.T.C. 1529, 1672-73).

${ }^{83} 8805-3-3-2$, pp. $43,151$. 
clear, then, that the three-year restriction imposed by the commission was binding.

The three-year duration is misleading, however, since almost all the contracts could be terminated on fairly short notice. About two-thirds of the contracts could be terminated on three to six months' notice if the parties failed to agree on a new price. Only two contracts-both with Mobil-allowed for termination without cause by either party (three months' notice was required) ${ }^{84}$

The salient feature of the post-1973 contracts is, not surprisingly, the focus on the problem of price adjustment. The response to the increased variability of prices was a substantial decrease in the period between price changes. The contracts split approximately evenly between those relying on indexing and those relying on renegotiation. Through the beginning of 1976 the price of crude oil was the basis for indexing. ${ }^{85}$ From July 1976 onward, however, if the contract provided for indexing, the only external price utilized was that of calcined coke.

The purpose of indexing in this period of high volatility was very different from its purpose in the previous period. There was no intention to ensure automatic price adjustment for the life of the contract. Rather it functioned as part of the renegotiation process. The index was only expected to be in force for short periods. Thus, half the contracts with prices indexed to crude oil called for renegotiation at a fixed interval of three to six months. The other half did not set a fixed date for renegotiation. Instead, they established a maximum and minimum (about 15 percent above and below the base price.) If the calculated price fell outside this range, one party could request price renegotiation. If the parties failed to agree on a new price, the contract would terminate in three months. Thus, indexing only provided a point of reference for renegotiation. That is, if one party did not accept the calculated price, it could request renegotiation, and, if the other party refused, it could terminate the agreement ${ }^{86}$ If the indexed price is expected to be closer to the market price than is the base price, then indexing would have reduced the rewards of opportunism associated with renegotiating the price.

Nine of the post-1973 GLC contracts were with Texaco-three contracts at three different sites. All nine contracts gave Texaco the right to

${ }^{84}$ A 1976 contract with Atlantic Richfield could be terminated after one year with 120 days notice.

${ }^{85}$ Eight contracts utilized indexes; all included the cost of crude oil; one added wages, and another added wages and refinery fuel costs and electricity (crude oil had a weight of 93 percent in this agreement).

${ }^{86}$ Appendix, Term 68. 
terminate the agreement if it received a bona fide offer above the contract price; however, GLC could continue the agreement by matching the higher price ${ }^{87}$ This arrangement was adopted to adjust the contract price to rapidly changing market conditions, not to facilitate termination. Rapid adjustment to objectively determined information meant that that the parties were less likely to engage in bickering and similar behavior that would reduce the probability of their renewing the contract. The Texaco contracts also utilized one other form of price adjustment that relied on the continuation of the long-term relationship between the two firms-ex post pricing. In 1974 and 1975, when Texaco and GLC could not reach an agreement on price by the contractually determined deadline, they agreed to extend the negotiating period for a stated period. In the interim, they continued to perform with GLC paying at the preexisting price. When agreement was finally reached, the new price was applied retroactively. Thus, two 1974 contracts were effective as of January 1 even though they were not signed until August 26 . $^{88}$

In 1973, aluminum producers were performing under minimum quantity, fixed-price contracts. The fixed-price contracts provided the aluminum companies with an unanticipated windfall. Rather than simply accepting the windfall until the contract expired, the aluminum companies had the option of trading off part of the windfall to enhance their future access. Access could, of course, be achieved in other ways. The aluminum company could acquire nearby land for storing inventory, or it could find alternative suppliers. A new coker could be constructed at a convenient location before the existing contract expired. Our discussions with industry sources suggest that, with one notable exception (discussed below), contract prices were renegotiated upward.

The new prices were not, however, necessarily tied to a formal extension of the contract. Kaiser, which had the most coke contracts, did not extend its agreements; rather, it shifted to three-year contracts. Moreover, the new Kaiser contracts included price-adjustment mechanisms similar to those of GLC. Contract price was typically indexed, but prices could be renegotiated if the indexed contract price was out of line. In the GLC agreements, renegotiation was triggered by mechanical rules. The price could be renegotiated if the indexed price hit the ceiling or floor, or if sufficient time had passed. Kaiser's trigger was an announcement by either party that the current price was unacceptable. In that event, the parties would have a short period (about three months) to renegotiate a

${ }^{87}$ Appendix, Term 69.
88 Appendix, Term 70. 
price; if they failed, the contract would terminate after another three months.

Kaiser's willingness to accept such a renegotiation arrangement appears surprising given its vulnerability to opportunistic behavior by its suppliers. The increased volatility made tracking of current price more valuable than in the pre-1973 period, but we would have expected the parties to choose a less manipulable rule; for example, price could have been indexed to external prices (such as crude oil or calcined coke) and the parties could have been given the right to solicit outside offers, with their counterpart having the right of first refusal. Kaiser's willingness to go further than this might be explained by two factors. First, Kaiser had become increasingly less vulnerable to the loss of a single coke supplier; it operated six calciners, with the largest accounting for approximately onefourth its capacity. Moreover, its calcined coke output had grown so that it now substantially exceeded Kaiser's internal needs. Kaiser looked more like a middleman than an aluminum company end user. Second, Kaiser's renegotiation of the fixed price, pre-1973 contracts might be viewed as an indication of its good faith; ceteris paribus, the more trust, the more viable the price renegotiation.

Kaiser's earlier contracts were indexed to crude oil, but most of the more recent ones were based on calcined coke prices. GLC's posted price of calcined coke was first used, but this proved unsatisfactory when GLC maintained the posted price in the early $1980 \mathrm{~s}$ in the face of a price decline of about 30-40 percent. ${ }^{89}$ Kaiser shifted to a measure based on actual Kaiser transaction prices that, although more subject to manipulation, better tracked the price of green coke.

The one exception regarding renegotiation was Richfield's contract with Harvey (subsequently Martin Marietta). The failure to renegotiate price led to considerable ill will, and the contract was allowed to expire in its fifteenth year. Richfield exercised its option to have the land returned and the calciner removed, ${ }^{90}$ although it did permit Marietta to operate the calciner after the agreement expired (until Marietta's new calciner came on line). Marietta was supplied by a new coker built by Champlin Oil; the new calciner, a joint venture with Champlin, was located adjacent to the coker. It is generally believed in the industry that the demolition of the calciner was an unnecessary and costly result of the decision not to renegotiate prices.

\footnotetext{
${ }^{89}$ Peter Fasullo, Tim Tarrillion, \& John Matson, Price of Dwindling Supply of BetterQuality Coke, Oil \& Gas J. 198 (November 8, 1982).

${ }^{90}$ See Appendix, Term 15.
} 


\section{Concluding Remarks}

The substantial amount of contractual detail we have provided indicates some of the ingenious solutions parties have devised for resolving some apparently intractable problems of coordination across organizational boundaries. We will not provide a full summary of all the features of the contracts. Instead, we will confine attention to a few points deserving special emphasis.

A refiner has to determine how much freedom it is willing to sacrifice in setting its rate of coke output, while a buyer must determine how much responsibility for accepting a given amount of coke it will bear. Since coke is a low value by-product accounting for less than 3 percent of the value of refined oil, the coker would prefer to decide how much coke it should produce on the basis of conditions in the oil market. Moreover, the less storage capacity available at the refinery, the more the refiner would value a buyer's promise to promptly remove whatever coke the refinery happens to produce. The full-output, immediate removal contracts that Great Lakes Carbon usually entered into provided the coker with this assurance. Nevertheless, when a coker entered into a contract in which it was to be the sole supplier of a calciner, it would almost invariably give up most of its freedom to determine its output rate in order to provide the buyer with sufficient assurance.

One of the most surprising findings was the frequent use of multipart, or nonlinear, prices to protect the seller's reliance. We must emphasize that considerable effort was necessary to reinterpret the contract language in a manner that would reveal the nonlinear pricing-this was not an easily observable fact that cried out for an explanation. We suspect that our efforts here will put subsequent researchers on guard and will result in the discovery of numerous other nonlinear pricing arrangements that had hitherto gone unnoticed.

Virtually all the GLC contracts that indexed to crude oil prices imposed maximum-minimum limits. However, while the maximum (minimum) was about 40-50 percent above (below) the base price in the low-inflation 1960s, it was only about 15 percent above (below) the base in the highinflation 1970s. It would seem contrary to intuition that the limits would shrink as the rate of inflation rises. The apparent paradox is resolved by recognizing that the limitations served a completely different function in the two periods. In the former, the index was in force for the life of the contract. The limits came into play only if some major unanticipated change occurred, at which time the parties would then be forced to renegotiate in order to take the new circumstances into account. The limits 
would be reached only under rather extraordinary circumstances. In the latter case, indexing provided a point of reference for renegotiation. Frequent renegotiation, which kept the contract price in line with current market conditions, could be triggered either by setting fixed dates to renegotiate (for example, at quarterly intervals) or by setting narrow boundaries on an indexed price-boundaries that the parties expected would routinely be reached.

Increased price volatility resulted in contracts that were of shorter duration and easier to terminate. This is, of course, inconsistent with the notion that the parties would enter into long-term contracts to protect themselves from price fluctuations. It appears that the increased price volatility raises the costs of long-term contracts relative to both shortterm contracts and integration by ownership.

We have had reasonable success explaining the structure of the petroleum coke contracts without invoking power, anticompetitive behavior, or risk preferences. Instead, we have focused on long-term reliance, short-term coordination, the costs of acquiring information, and other "relational"' concepts. While a single case study may not prove anything, it can suggest which research strategies are more likely to prove fruitful. Furthermore, since the economic theory of contracts has heretofore largely ignored the empirical data, case studies of this sort should lead to a reshaping of the theorists' research agenda-a reshaping that would give more weight to the sorts of issues that prove to be important in this market. 